MATEC Web of Conferences 10,06004 (2014)

DOI: $10.1051 /$ matecconf/ 20141006004

(C) Owned by the authors, published by EDP Sciences, 2014

\title{
Investigation of Fire Safety Awareness and Management in Mall
}

\author{
N. Abdul Rahim ${ }^{1}$, M. Taib ${ }^{2, a}$, M.A. Othuman Mydin ${ }^{3}$ \\ ${ }^{1,2,3}$ School of Housing, Building and Planning, Universiti Sains Malaysia, 11800, Penang, Malaysia
}

\begin{abstract}
In spite of having sufficient fire safety system installed in buildings, the incidence of fire hazard becomes the furthermost and supreme threat to health and safety, as well as property to any community. In order to make sure that the safety of the building and its users, the fundamental features depends on the fire precaution system and equipment which should be according to the standard requirements. Nevertheless, the awareness on fire safety could necessarily alleviate the damages or rate of fatality during the event of fire. This paper presents the results on the investigation of fire safety awareness and management, concentrating on shopping mall. The endeavour of this study is to explore the level of fire safety knowledge of the users in the mall, and to study the effectiveness level of fire safety management in a mall. From the study, public awareness is highly related to understanding human behaviour and their personal background. The respondents' levels of awareness are rather low, which reflects on their poor action when facing emergency situation during fire. The most effective methods identified to improve the awareness and effectiveness of fire safety level is through involvement in related fire safety programmes, distribution of pamphlets or brochures on fire safety and appointing specific personnel for Emergency Response Team in the mall.
\end{abstract}

\section{Introduction}

The occurrence of accidental fires in shopping mall can be more detrimental since experience has shown that the worst fires are the result of many factors dysfunction or just go wrong. The potential of fire risk is measured to be high as the shops within the building has the highest fire load density (FLD) for instance products such as curtains, blankets, pillows and mattresses, hence the highest potential fire hazard. It is essential to know that fire safety is not dynamics, which includes smoke control, sprinkler systems, detection, fire departments, structural fire endurance or fire prevention or risk management. The fire safety includes all these crucial elements [1].

This shopping mall building is essentially at higher risk because it is also used as administrative centre for government offices. Thus, the number of public visitors is high even during normal office hours, as compared to typical type which is mostly crowded during the weekends. Although the building is provided with the updated and advanced fire safety equipment, the safety of building occupants is uncertain in the case of a fire. Despite good conditions of the fire protection system, fire problems may still occur and will be difficult to deal with, particularly when it involves public visitors as they are not familiar with the building environment and its layout.

\footnotetext{
${ }^{a}$ Corresponding author: mariati@usm.my
} 
Fire can take place in the building at any time, originating from many sources. From the moment of ignition there is a potential of major disaster, and it is just a matter of time before it became fatal. The best defence against injury or possible loss of life from fire has always depended on strong fire prevention and safety systems. Such system must be fully handled by all responsible authorities, with regard to the following three elements such as education, training and attitude. However, the awareness of public shoppers or visitors may increase or alleviate the percentage of total mortality, costs and other loss.

\section{Research Methodology}

The method used in carrying out the study was determined in order to achieve its objectives. This section is going to review the methods applied in collecting the data to determine the level of knowledge of the users' of public building. Next, field research was conducted based on the case studies that were previously identified in the scope of work. This research focused on high-rise building, Kompleks Tun Abdul Rahman (KOMTAR) as been shown in Figure 1 which is located in Penang and the focus was only at the podium area which starts from the 1 st floor until the 4th floor.

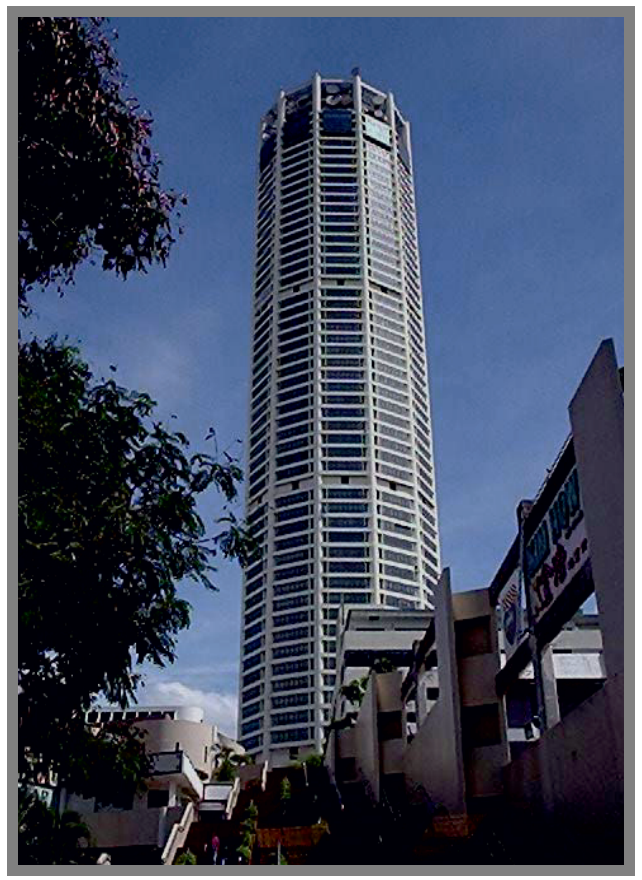

Figure 1. Kompleks Tun Abdul Rahman (KOMTAR)

The scope of study is limited to the podium area as it is fully accommodated and mostly used in the building. In total, 100 questionnaire responses were obtained during field data collection. The questionnaire was designed in a user-friendly multiple-choice format without any open-ended questions. The respondent groups are concentrated on public visitors as well as building occupants working in the building. Personal interviews were also conducted involving day operations personnel, such as Executive Facilities, Maintenance Manager, Technicians and others. This was necessary to obtain their professional opinions as what has been stated in the objectives of the study.

From the information obtained through the literature and personal interview, the questionnaire was developed and distributed to the targeted participants. Subsequently, the data obtained from the questionnaires were analyzed and their inferences were presented. Besides that, the data were also analyzed with regard to the Likert Scale formula. 
Table 1. Summary of the Survey Results on the Level of Knowledge of the Respondents in the Mall

\begin{tabular}{|c|c|c|c|c|c|c|c|c|c|c|}
\hline \multirow{3}{*}{\multicolumn{2}{|c|}{$\begin{array}{l}\text { The Level of Knowledge of the } \\
\text { Respondents in the Mall }\end{array}$}} & \multicolumn{6}{|c|}{ No. of Respondents } & \multirow{3}{*}{$\begin{array}{l}\text { Average } \\
\text { Index }\end{array}$} & \multirow{3}{*}{ Status } & \multirow{3}{*}{ Rank } \\
\hline & & \multicolumn{5}{|c|}{ Scale } & \multirow{2}{*}{ Total } & & & \\
\hline & & 1 & 2 & 3 & 4 & 5 & & & & \\
\hline 1) & $\begin{array}{l}\text { Number to be Contact in the Case of } \\
\text { Fire }\end{array}$ & 11 & 11 & 27 & 15 & 36 & 354 & 3.54 & $\begin{array}{c}\text { Very } \\
\text { Effective }\end{array}$ & 1 \\
\hline 2) & $\begin{array}{l}\text { Emergency Contact of the Person in } \\
\text { Charge in the Mall during the } \\
\text { Emergency of Fire }\end{array}$ & 24 & 15 & 20 & 21 & 20 & 298 & 2.98 & $\begin{array}{l}\text { Moderately } \\
\text { Effective }\end{array}$ & 3 \\
\hline 3) & $\begin{array}{l}\text { Procedures that must do when Fire } \\
\text { Occur }\end{array}$ & 12 & 16 & 28 & 23 & 21 & 325 & 3.25 & $\begin{array}{c}\text { Moderately } \\
\text { Effective }\end{array}$ & 2 \\
\hline 4) & $\begin{array}{l}\text { Attend any Fire Safety Activities } \\
\text { Organized by Fire \& Rescue Dept. or } \\
\text { any Organizations }\end{array}$ & 33 & 15 & 15 & 24 & 13 & 269 & 2.69 & $\begin{array}{l}\text { Moderately } \\
\text { Effective }\end{array}$ & 5 \\
\hline 5) & Been Participating in a Fire Drill & 26 & 21 & 14 & 22 & 17 & 283 & 2.83 & $\begin{array}{c}\text { Moderately } \\
\text { Effective }\end{array}$ & 4 \\
\hline
\end{tabular}

\section{Data Collection and Data Analysis}

\subsection{The Level of the Knowledge of the Respondents in the Mall}

From the perspective of public visitors, the awareness are measured based on their response in the case of fire occurrence. Based on the questionnaires, the summary of the survey results are given as average index shown in Table 1. The average index is based on the overall total of 100 respondents.

Overall, the response given by the visitors range from moderately effective to very effective. The highest score of 3.54 was given based on the question whether the visitors know the emergency number to be contacted during fire events. Following that, an average of 3.25 was given based on whether they now the procedures to be taken if fire occur. It shows that most of the respondents have the basic knowledge acquired during emergency. This includes identifying the nearest fire exits, usage of the fire protection systems for instance the fire extinguishers and handling the fire area appropriately.

Meanwhile lowest average rate of 2.69 is given by the survey of the frequency of attending any fire safety activities organized by either the Fire \& Rescue Department or any other organization. From the method survey, it can be concluded that the level of knowledge of the respondents, which included the occupants and visitors are moderately effective. Level of knowledge of the respondents remains at a moderate pace and should be further improved.

\subsection{The Level of the Effectiveness of Fire Safety Management and the Public Awareness of Fire Safety Knowledge}

In this part of survey, it targeted the management level which has the authority to ensuring the level of fire safety system of the building. Overall, all the survey resulted to moderately effective status. This proves that the respondents' knowledge level on fire safety management is still at moderate level. Table 2 shows the results of the respondents' level of knowledge on fire safety management in KOMTAR.

From the table, it can be seen that they tend to give immediate response to the alarm signals in the event of fire and this question was in the first rank, which yielded the highest average index of 3.50. This shows that the alarm signal was still effective in serving its purpose of giving warning during emergency situation to the occupants. Quick response to alarm signal is important because early warning make known to the building occupants during emergency may prevent or reduce loss of lives or property. 
Table 2. Summary of the Survey Results on the Level of the Effectiveness of Fire Safety Management and the Public Awareness of Fire Safety knowledge

\begin{tabular}{|c|c|c|c|c|c|c|c|c|c|}
\hline \multirow{3}{*}{$\begin{array}{l}\text { The Level Of The Effectiveness Of Fire } \\
\text { Safety Management And The Public } \\
\text { Awareness Of Fire Safety Knowledge }\end{array}$} & \multicolumn{6}{|c|}{ No. of Respondents } & \multirow{3}{*}{$\begin{array}{c}\text { Average } \\
\text { Index }\end{array}$} & \multirow{3}{*}{ Status } & \multirow{3}{*}{ Rank } \\
\hline & \multicolumn{5}{|c|}{ Scale } & \multirow{2}{*}{ Total } & & & \\
\hline & 1 & 2 & 3 & 4 & 5 & & & & \\
\hline 1) Exit Route in this Mall & 14 & 11 & 23 & 29 & 23 & 336 & 3.36 & $\begin{array}{l}\text { Moderately } \\
\text { Effective }\end{array}$ & 3 \\
\hline $\begin{array}{l}\text { 2) Tend to give immediate respond to } \\
\text { the Alarm Signals in the Event of } \\
\text { Fire }\end{array}$ & 10 & 11 & 26 & 25 & 28 & 350 & 3.50 & $\begin{array}{l}\text { Moderately } \\
\text { Effective }\end{array}$ & 1 \\
\hline $\begin{array}{l}\text { 3) Know the Location Place of } \\
\text { Assembly of this Building during } \\
\text { Fire }\end{array}$ & 19 & 20 & 25 & 19 & 17 & 295 & 2.95 & $\begin{array}{l}\text { Moderately } \\
\text { Effective }\end{array}$ & 4 \\
\hline $\begin{array}{l}\text { 4) Aware that the use of Elevators } \\
\text { during a Fire should be avoided? }\end{array}$ & 14 & 15 & 15 & 20 & 36 & 349 & 3.49 & $\begin{array}{l}\text { Moderately } \\
\text { Effective }\end{array}$ & 2 \\
\hline
\end{tabular}

Besides that, the awareness on the use of elevators during a fire should be avoided was in the second rank with the average index of 3.49. We should know that the use of elevators during fire is strongly prohibited. The fire safety management on exit route in this mall was in the third rank with an average index of 3.36 .

This means that the occupants in general have moderate knowledge in fire safety management on exit route in this building. The respondents should know which routes should be taken when an emergency situation happens. By knowing the exit or escape route, it can make the respondents more manageable and in control and could make them less panic during an emergency situation.

The knowledge on the location of the place of assembly of this building during fire was on the last rank which was in average index of 2.95 and the status of this index was in moderately effective. It shows that some of the respondents did not know the exact location of the place for assembly.

From the method of calculating the average, it can be said that the level of the effectiveness of fire safety management and the public awareness on fire safety knowledge among respondents including occupants and visitors are in moderately effective status. Level of knowledge of the respondents remained at a moderate pace and should be further improved.

\subsection{To Identify the Methods of Educating Building Occupants on Fire Safety}

Respondents' opinion was that by having this program, it was very effective as compared to all the methods suggested (Table 3). It was ranked first with an average index of 4.12 which means that it was very effective. Although it can be costly and has to be undertaken by the government or related organizations, but it was still worth it because it can reach wide range of audiences and reduce the fire accidents thus saving many lives and avoid loss of valuable assets. Besides that, by conducting this program it will help to prepare users to face a real fire situation in the event it occurs.

By distributing the pamphlets which contain the emergency procedures and evacuation plans to the building users, it can be concluded that it was a part of an education syllabus. It was ranked second with an average index of 3.70, so definitely it was in the very effective status.

By distributing the pamphlets, it will help to increase the level of knowledge in fire safety management among the respondents in this building.

Next, third in the rank, was to appoint the specific personnel as Emergency Response Team who was specially trained for emergency situations at the malls. It was in average index of 3.49 which means moderately effective. In this system, specific persons were employed as a team to ensure that fire safety is in good condition in that building. By creating the organizations, it will help the building user to get the information and basic knowledge about fire safety. 
Table 3. Summary Survey Results on the Level of the Effectiveness of Fire Safety Management and the Public Awareness of Fire Safety Knowledge

\begin{tabular}{|c|c|c|c|c|c|c|c|c|c|}
\hline \multirow{3}{*}{$\begin{array}{l}\text { To identify the methods to improve the } \\
\text { knowledge among users on fire safety }\end{array}$} & \multicolumn{6}{|c|}{ No. of Respondents } & \multirow{3}{*}{$\begin{array}{l}\text { Average } \\
\text { Index }\end{array}$} & \multirow{3}{*}{ Status } & \multirow{3}{*}{ Rank } \\
\hline & \multicolumn{5}{|c|}{ Scale } & \multirow{2}{*}{ Total } & & & \\
\hline & 1 & 2 & 3 & 4 & 5 & & & & \\
\hline $\begin{array}{l}\text { 1) Specific Personnel as Emergency } \\
\text { Response Team whom is Specially } \\
\text { Trained for Emergency Situations at } \\
\text { the Mall }\end{array}$ & 14 & 15 & $\begin{array}{l}1 \\
5\end{array}$ & 20 & $\begin{array}{l}3 \\
6\end{array}$ & 349 & 3.49 & $\begin{array}{l}\text { Moderately } \\
\text { Effective }\end{array}$ & 3 \\
\hline 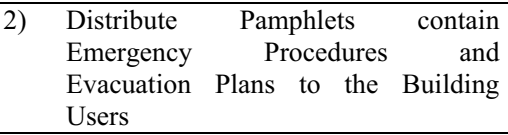 & 8 & 10 & $\begin{array}{l}1 \\
9\end{array}$ & 30 & $\begin{array}{l}3 \\
3\end{array}$ & 370 & 3.70 & $\begin{array}{l}\text { Very } \\
\text { Effective }\end{array}$ & 2 \\
\hline $\begin{array}{llll}3) & \text { Tagline "Fire } & \text { Prevention } & \text { Our } \\
\text { Responsibility" } & & \\
\end{array}$ & 11 & 14 & $\begin{array}{l}2 \\
2\end{array}$ & 25 & $\begin{array}{l}2 \\
8\end{array}$ & 345 & 3.45 & $\begin{array}{l}\text { Moderately } \\
\text { Effective }\end{array}$ & 4 \\
\hline $\begin{array}{l}\text { 4) Interested in being involved with the } \\
\text { Programmed }\end{array}$ & 2 & 5 & $\begin{array}{l}2 \\
0\end{array}$ & 25 & $\begin{array}{l}4 \\
8\end{array}$ & 412 & 4.12 & $\begin{array}{c}\text { Very } \\
\text { Effective }\end{array}$ & 1 \\
\hline
\end{tabular}

Most of the respondents felt that this system was not practical because it would involve a very high cost, since the building management would have to employ many people. This cost would ultimately be passed down to the end-users in the form of higher maintenance fees. Most people are not willing to pay these high fees, thus tendering this system to be impractical. But most of the current management has appointed ERT staff among their self typically those with expertise in the areas of building maintenance as a measure to save costs.

Lastly, the tagline "Fire Prevention Our Responsibility" was in the fourth rank with the average of 3.45 and was considered moderately effective but it was not the favourite choice according to the survey compared to all the methods suggested.

\section{Conclusions}

From the analysis, this study has successfully identified and met the three objectives that were previously stated in the introduction. Overall, it can be said that the level of knowledge of the respondents were in a moderate level based on the conclusion to the five questions above. Many improvements need to be done to improve their level of knowledge with regard to the importance of fire safety. Lack of preparedness also resulted in the lack of respondents' knowledge on the particular subject matter. If this issue was underestimated, it would lead to danger as it can lead to panic and cause severe loss in case of a major fire in the area. This is exactly the aim of fire safety management, which is to educate users to be more responsible and proactive towards fire safety.

\section{References}

1) R.W. Fitzgerald, Building Fire Performance Analysis, 2004, p: 79.

2) C. Subramaniam, Human factors influencing fire safety measures, Journal of Disaster Prevention \& Management, 13 (2) (2004) 110-116.

3) D. Canter, Fire and Human Behavior - An Introduction, 1980, pp: 3-7.

4) J. Sime, Escape Behavior in Fires and Evacuations, Design against Fire: An Introduction to Fire Safety Engineering Design, 1994, p: 65. 